\title{
Cardiovascular disease, mortality, and magnesium in chronic kidney disease: growing interest in magnesium-related interventions
}

Ryota Ikee

\begin{abstract}
Magnesium (Mg) is an essential element that plays pivotal roles in a number of biological processes in the human body. Hypomagnesemia is involved in the pathophysiology of hypertension, vascular calcification, and metabolic derangements including diabetes mellitus and dyslipidemia, which are all risk factors for cardiovascular disease, the leading cause of mortality and morbidity in patients with chronic kidney disease (CKD). Hypomagnesemia is also associated with the development and progression of CKD. As CKD advances, renal Mg excretion decreases and hypermagnesemia emerges in end-stage renal disease (ESRD). In addition, dialysates with high Mg concentrations, which were used in the early era of dialysis therapy, increased the risk of hypermagnesemia, and thus, the dialysate Mg composition has since been reduced. Accordingly, dialysis patients in the modern era commonly have normomagnesemia or even hypomagnesemia. The relationships between hypomagnesemia and cardiovascular disease and mortality have been increasingly reported in observational studies in CKD/ESRD. However, these relationships may be attenuated by a patient's race or region. Although dialysates with higher Mg concentrations or Mg-containing phosphate binders appear to be promising in this setting, only a few interventional studies have examined the effects of $\mathrm{Mg}$ supplementation on cardiovascular lesions. Furthermore, the effects of $\mathrm{Mg}$ supplementation on mortality have not yet been investigated as a primary end-point in randomized controlled trials. Further studies are required in order to establish the efficacy and safety of Mg in CKD patients.
\end{abstract}

Keywords: Magnesium, Chronic kidney disease, Dialysis, Cardiovascular disease, Vascular calcification, Mortality, Dialysate composition, Phosphate binder

\section{Background}

Magnesium (Mg), the fourth most abundant cation in the human body, is a co-factor in more than 300 enzyme systems that regulate a number of biological processes, such as protein synthesis, muscle and nerve transmission, neuromuscular conduction, and signal transduction. It is also involved in the cardiovascular system via the regulation of vascular tone, heart rhythm, endothelial function, and platelet-activated thrombosis [1-5]. An insufficient $\mathrm{Mg}$ intake and hypomagnesemia are associated with inflammation, oxidative stress, and metabolic derangements, such as diabetes mellitus (DM) and dyslipidemia [5-8], all

\section{Correspondence: ryota.ikee@gmail.com}

Department of Nephrology and Dialysis, H. N. Medic Kitahiroshima, 5-6-1 Kyoeicho, Kitahiroshima, Hokkaido 061-1113, Japan of which contribute to the development of cardiovascular disease. It is well known that cardiovascular mortality is 10-30-fold higher in dialysis patients than in the general population [9]. Recent clinical studies reported the negative impact of hypomagnesemia in patients with chronic kidney disease (CKD). The potentially protective role of $\mathrm{Mg}$ in this population has been attracting increasing attention. We herein review clinical studies that examined the effects of serum Mg levels on cardiovascular disease and mortality and discuss Mg-related interventions in CKD patients.

\section{Mg and the kidney}

The human body stores approximately $25 \mathrm{~g}$ of $\mathrm{Mg}$ : $66 \%$ of this is in bone, $33 \%$ in intracellular spaces, 
and $1 \%$ in extracellular spaces $[5,10]$. Serum $\mathrm{Mg}$ levels in healthy subjects are maintained within a narrow range primarily by the balance between intestinal absorption and renal excretion. In the kidney, most $\mathrm{Mg}$ filtered by the glomeruli is immediately reabsorbed and only $3-5 \%$ is excreted in the urine [5]. Reabsorption occurs in the ascending limb of Henle's loop mainly via paracellular transport, and transcellular transport in the distal convoluted segment contributes to maintaining the regulation of $\mathrm{Mg}$. Renal tubular reabsorption of $\mathrm{Mg}$ is increased by extracellular volume contraction, hypomagnesemia, and high parathyroid hormone (PTH) levels [10].

Several observational studies identified hypomagnesemia as a predictor of a decline in renal function [11-14]. Tin et al. evaluated the risk of renal function loss in association with serum $\mathrm{Mg}$ levels in 13,226 patients during a median follow-up period of 21 years [13]. In a multivariate analysis adjusted for demographics, baseline renal function, nutrition markers, and comorbidities, patients with low serum Mg levels $\leq 1.70 \mathrm{mg} /$ $\mathrm{dL}(0.70 \mathrm{mmol} / \mathrm{L})$ showed a $58 \%$ higher hazard ratio (HR) for incident CKD and a 139\% higher HR for end-stage renal disease (ESRD) than those with the highest quartile of serum Mg levels $(2.19-2.80 \mathrm{mg} / \mathrm{dL}$ [0.90-1.15 mmol/L]). Sakaguchi et al. demonstrated a significant interaction between serum $\mathrm{Mg}$ and $\mathrm{P}$ levels on CKD progression [14]. Among 311 non-diabetic CKD patients, those in the lower $\mathrm{Mg}$ and higher $\mathrm{P}$ group were at a 2.07-fold risk for incident ESRD compared with those in the higher $\mathrm{Mg}$ and higher $\mathrm{P}$ group. The mechanisms contributing to the relationship between hypomagnesemia and renal function loss have not yet been elucidated in detail, but endothelial dysfunction, inflammation, vascular calcification, DM, insulin resistance, hyperaldosteronism, and pro-thrombotic effects may be involved $[13,15]$. Lower dietary $\mathrm{Mg}$ intake may also induce renal function loss [16].

Glomerular filtration of $\mathrm{Mg}$ decreases as CKD progresses, whereas tubular reabsorption of $\mathrm{Mg}$ is impaired due to tubulointerstitial injury, thus causing an increase in fractional $\mathrm{Mg}$ excretion $[17,18]$. However, the quantitative excretion of $\mathrm{Mg}$ tends to decrease regardless of the compensatory increase in fractional $\mathrm{Mg}$ excretion if glomerular filtration rate (GFR) falls to $<30 \mathrm{~mL} / \mathrm{min} /$ $1.73 \mathrm{~m}^{2}$ [19], particularly $<10-15 \mathrm{~mL} / \mathrm{min} / 1.73 \mathrm{~m}^{2}[20$, 21]. Overt hypermagnesemia emerges when GFR falls to $<10 \mathrm{~mL} / \mathrm{min} / 1.73 \mathrm{~m}^{2}$ [20]. Previous studies reported an inverse correlation between renal function and serum Mg levels in non-diabetic CKD [11, 22]. However, this correlation was not observed in diabetic CKD [11, 22], which would be attributable to an insulin-induced increase in renal Mg excretion leading to hypomagnesemia in diabetic patients [5, 23].

\section{Mg and dialysis therapy}

Dialysate $\mathrm{Mg}$ concentrations are one of the main factors influencing the $\mathrm{Mg}$ balance and serum $\mathrm{Mg}$ levels in dialysis patients. $\mathrm{Mg}$ easily crosses the hemodialyzer membrane and peritoneal membrane, and the amount of $\mathrm{Mg}$ elimination depends on its concentration gradient between serum and dialysate. A small amount of $\mathrm{Mg}$ is also removed by ultrafiltration. Actually, hypertonic dialysate use has been associated with hypomagnesemia in patients treated with peritoneal dialysis (PD) [24]. Dialysate $\mathrm{Mg}$ concentrations have changed over time. Until the 1980s, hemodialysis (HD) dialysate with a Mg concentration of $0.75 \mathrm{mmol} / \mathrm{L}$ was commonly used, while that with a lower concentration of $0.5 \mathrm{mmol} / \mathrm{L}$ is now widely used. In $\mathrm{PD}$, dialysate $\mathrm{Mg}$ concentrations have changed from 0.75 to $0.25 \mathrm{mmol} / \mathrm{L}$. These changes may be attributable to concerns regarding the suggestion by some studies of the adverse influence of hypermagnesemia on renal osteodystrophy [25], uremic pruritus [26], and visceral calcification [27] and the introduction of Mg-containing phosphate binders. Serum Mg levels in dialysis patients have been decreased by the changes of dialysate $\mathrm{Mg}$ concentrations, and hypomagnesemia rather than hypermagnesemia is now becoming an issue of interest due to its potent harmful influence. Hypomagnesemia is more common in PD patients than in HD patients because of lower dialysate $\mathrm{Mg}$ concentrations as well as the continuous nature of PD therapy.

Dietary $\mathrm{Mg}$ intake is another factor that influences serum $\mathrm{Mg}$ levels [28]. Dietary $\mathrm{Mg}$ is mainly absorbed in the small intestine. The active form of vitamin $D$ has been shown to stimulate intestinal $\mathrm{Mg}$ absorption [5], which may partly explain depressed $\mathrm{Mg}$ absorption reported in CKD patients with a deficiency in active vitamin D [29]. Schmulen et al. previously showed that the administration of vitamin $\mathrm{D}$ receptor activators enhanced intestinal $\mathrm{Mg}$ absorption in CKD patients [30]. Mg-rich foods include green vegetables, peas, beans, nuts, seeds, and some fish [28], which are often restricted to avoid hyperkalemia and hyperphosphatemia. Therefore, dietary $\mathrm{Mg}$ intake may be insufficient, particularly in dialysis patients, as described by Luis et al. [31]. Serum Mg levels may be used as nutritional markers in dialysis patients because they correlate with serum albumin levels [24, 32$36]$, body mass index [24, 32], normalized protein catabolic rate [32, 34, 36], muscle mass [32] and strength [37], and subjective global assessment scores [32]. Of interest, the use of a low Mg PD dialysate induced a decrease in serum albumin levels [38].

In order to treat the complications that occur during long-term CKD, a number of drugs, such as diuretics, antibiotics, chemotherapeutic agents, $\beta$-blockers, and proton-pump inhibitors, are often used and may induce hypomagnesemia [5]. 


\section{Observational studies on hypomagnesemia, cardiovascular disease, and mortality}

In CKD patients, cardiovascular calcification begins during the pre-dialysis period and relentlessly progresses after the induction of dialysis therapy [39, 40]. In addition to hypertension, inflammation, an increase in serum $\mathrm{Ca} / \mathrm{P}$ levels, the high prevalence of DM and warfarin use, and chronic micro-inflammation [41], hypomagnesemia may accelerate the progression of vascular calcification. Recently, the mechanisms of inhibition of vascular calcification by Mg have been widely investigated in experimental studies. Currently, there are two leading hypotheses [42]. First, Mg may bind P and delay Ca-P crystal growth in the circulation, thereby passively interfere with $\mathrm{Ca}-\mathrm{P}$ deposition in the vessel wall. Elevated serum $\mathrm{Mg}$ interferes with amorphous $\mathrm{Ca}-\mathrm{P}$ maturation into hydroxyapatite [43]. Calciprotein particle (CPP) is a recent issue of interest. $\mathrm{Ca}$ and $\mathrm{P}$ combine with fetuin-A to form amorphous $\mathrm{Ca}-\mathrm{P}$ containing primary CPPs. Primary $\mathrm{CPP}$ is considered to inhibit crystal growth and aggregation [44], but it undergo spontaneous maturation and develop crystalline structures to form secondary CPP. Aghagolzadeh et al. have recently reported that secondary $\mathrm{CPP}$ has a potential to induce vascular calcification [45]. In addition, CPP maturation time $\left(T_{50}\right)$ has been reported as an independent predictor of mortality in HD patients [46] and renal transplant recipients [47]. It is notable that $\mathrm{Mg}$ suppresses CPP maturation [48]. Second, Mg may regulate transdifferentiation of vascular smooth muscle cells (VSMC) toward an osteogenic phenotype by active cellular modulation of factors associated with calcification. It has been reported that $\mathrm{Mg}$ suppresses expression of osteogenic transcription factors (bone morphogenetic protein [BMP]-2, runtrelated transcription factor 2, Msh homeobox 2, SRY-box 9), bone proteins, and genes associated with matrix mineralization (osteocalcin, alkaline phosphatase) [42]. In addition, $\mathrm{Mg}$ prevents the loss of calcification inhibitors (BMP-7, matrix Gla protein, osteopontin) that protect against osteogenic conversion [42]. Montes de Oca et al. reported that $\mathrm{Mg}$ inhibited $\mathrm{Wnt} / \beta$-catenin signaling pathway and reversed osteogenic transformation of VSMC [49]. Mg transport through the cell membrane mediated by transient receptor potential melastatin 7 (TRPM7) is important in VSMC calcification [49-51]. Previous studies have suggested that $\mathrm{P}$ uptake through phosphate transporter-1 (Pit-1) is also essential in calcification [52]. Sonou et al. reported that $\mathrm{Mg}$ supplementation decreased Pit-1 protein expression in aortic rings incubated in highphosphate medium [51].

PTH has been suggested to be involved in vascular calcification [53, 54]. Serum Mg levels showed an independent inverse relationship with intact PTH levels in pre-dialysis ESRD patients [55] and dialysis patients [56, 57]. Interventional studies showed that dialysate $\mathrm{Mg}$ concentration and Mg-containing phosphate binders affected intact PTH levels [58, 59]. Mg suppresses PTH secretion via the activation of $\mathrm{Ca}$ sensing receptor, although Mg is 2- to 3-fold less potent than Ca. Suppression of PTH secretion induced by $\mathrm{Mg}$ supplementation may have a favorable effect on vascular calcification to some extent.

Changes in serum Mg levels during HD sessions may acutely influence cardiovascular hemodynamics and electrophysiological functioning. Kyriazis et al. investigated the influence of intradialytic changes in serum $\mathrm{Mg}$ levels on blood pressure [60]. Decreased serum $\mathrm{Mg}$ levels induced by a low $\mathrm{Mg}$ dialysate enhanced susceptibility to intradialytic hypotension, possibly because of impaired cardiac contractility. Limited information is currently available on the effects of $\mathrm{Mg}$ on arrhythmia, but Alabd et al. reported that the post-dialysis QTc interval duration inversely correlated with a decrease in serum Mg levels during the HD session [61].

Table 1 shows observational studies that examined the relationship between serum $\mathrm{Mg}$ levels and cardiovascular calcification/atherosclerosis in CKD/ESRD patients [32, 62-68]. Most of these studies indicated an association between hypomagnesemia and cardiovascular lesions. Sakaguchi et al. performed a cross-sectional study to evaluate coronary artery calcification using multidetector-row computed tomography in 109 pre-dialysis CKD patients with DM [67]. A multivariate analysis showed that serum Mg levels were inversely associated with the density of coronary artery calcification, after adjustments for demographics, renal function, and indices related to nutrition, inflammation, and mineral and bone disorders. This relationship was more pronounced in patients with serum phosphate levels $\geq 3.4 \mathrm{mg} / \mathrm{dL}$ $(1.40 \mathrm{mmol} / \mathrm{L})$. Liu et al. reported an independent relationship between hypomagnesemia and carotid intimamedia thickness (IMT) in $98 \mathrm{HD}$ patients [32].

The relationship between serum Mg levels and mortality in CKD patients is shown in Table 2 [12, 33-35, 69-72]. Van Laecke et al. found that adjusted HR for all-cause mortality decreased by $7 \%$ with a $0.1-\mathrm{mg} / \mathrm{dL}(0.04 \mathrm{mmol} /$ L) increase in serum Mg levels in non-dialysis CKD patients [12]. In the study by Cai et al. which included 253 incident PD patients, all-cause and cardiovascular mortalities were significantly lower in the high-serum-Mg group than in the low-Mg group [35]. Yang et al. examined 10,692 incident PD patients in the USA and found a significant association between hypomagnesemia and hospitalization [72]. However, hypomagnesemia was not an independent predictor of all-cause death after adjustments for laboratory variables. In HD patients, Ishimura et al. were the first to report an independent relationship between hypomagnesemia and all-cause mortality [73]. This study included 515 patients, and the mortality risk 
Table 1 Observational studies examining the relationship between serum Mg levels and cardiovascular calcification/atherosclerosis

\begin{tabular}{|c|c|c|c|c|c|}
\hline Authors (year) & Subjects & Study design & $\begin{array}{l}\text { Dialysate } \mathrm{Mg} \\
(\mathrm{mmol} / \mathrm{L})\end{array}$ & Outcome & $\begin{array}{l}\text { Adverse effects of } \\
\text { hypomagnesemia }\end{array}$ \\
\hline $\begin{array}{l}\text { Meema et al. } \\
\text { (1987) [62] }\end{array}$ & $44, P D$ & $\begin{array}{l}\text { Prospective follow-up for an } \\
\text { average of } 27 \text { months }\end{array}$ & 0.75 & $\begin{array}{l}\text { Progression and regression of artery calcification } \\
\text { evaluated by plain X-ray }\end{array}$ & Yes \\
\hline $\begin{array}{l}\text { Tzanakis et al. } \\
\text { (1997) [63] }\end{array}$ & $56, \mathrm{HD}$ & Cross-sectional analysis & 0.81 & $\begin{array}{l}\text { Mitral annular calcification detected by } \\
\text { echocardiography }\end{array}$ & Yes \\
\hline $\begin{array}{l}\text { Tamashiro et al. } \\
\text { (2001) [64] }\end{array}$ & $24, \mathrm{HD}$ & $\begin{array}{l}\text { Prospective follow-up for an } \\
\text { average of } 17 \text { months }\end{array}$ & 0.5 & $\begin{array}{l}\text { Changes in coronary artery calcification scores } \\
\text { evaluated by CT }\end{array}$ & No \\
\hline $\begin{array}{l}\text { Tzanakis et al. } \\
\text { (2004) [65] }\end{array}$ & 93, HD & Cross-sectional analysis & 0.48 & $\begin{array}{l}\text { Carotid intima-media thickness evaluated by } \\
\text { ultrasound }\end{array}$ & Yes \\
\hline $\begin{array}{l}\text { Ishimura et al. } \\
\text { (2007) [66] }\end{array}$ & $\begin{array}{l}\text { 390, HD, non- } \\
\text { DM }\end{array}$ & Cross-sectional analysis & 0.5 & $\begin{array}{l}\text { Arterial calcification of the hands detected by } \\
\text { plain X-ray }\end{array}$ & Yes \\
\hline $\begin{array}{l}\text { Liu et al. (2013) } \\
\text { [32] }\end{array}$ & $98, \mathrm{HD}$ & Cross-sectional analysis & 0.5 & $\begin{array}{l}\text { Carotid intima-media thickness evaluated by } \\
\text { ultrasound }\end{array}$ & Yes \\
\hline $\begin{array}{l}\text { Sakaguchi et al. } \\
\text { (2016) [67] }\end{array}$ & $\begin{array}{l}\text { 109, pre-dialysis } \\
\text { CKD, DM }\end{array}$ & Cross-sectional analysis & - & $\begin{array}{l}\text { Density of coronary artery calcification evaluated } \\
\text { by CT using Agatston scores }\end{array}$ & Yes \\
\hline $\begin{array}{l}\text { Molnar et al. } \\
\text { (2017) [68] }\end{array}$ & $80, \mathrm{PD}$ & Cross-sectional analysis & 0.25 & $\begin{array}{l}\text { Abdominal aortic calcification scores on lateral } \\
\text { lumbar spine X-ray }\end{array}$ & Yes \\
\hline
\end{tabular}

Abbreviations: $C K D$ chronic kidney disease, $C T$ computed tomography, $D M$ diabetes mellitus, $H D$ hemodialysis, $P D$ peritoneal dialysis

decreased by $52 \%$ with a $1-\mathrm{mg} / \mathrm{dL}$ increase in serum $\mathrm{Mg}$ levels. Recently, similar findings have been increasingly reported in large-scale studies [33, 34, 69-71]. Sakaguchi et al. examined this relationship using the Japanese National Registry data [69]. Although the follow-up period was limited to 1 year, the lowest $\mathrm{Mg}$ sextile group (serum $\mathrm{Mg}$ levels $<2.3 \mathrm{mg} / \mathrm{dL}$ [0.95 mmol/L]) showed the highest allcause and non-cardiovascular mortality risks, whereas the second highest $\mathrm{Mg}$ sextile (2.8-3.1 $\mathrm{mg} / \mathrm{dL}$ [1.15$1.28 \mathrm{mmol} / \mathrm{L}])$ showed the lowest mortality risk. It was notable that the second highest all-cause mortality risk and highest cardiovascular mortality risk were found in the highest $\mathrm{Mg}$ sextile $(\geq 3.1 \mathrm{mg} / \mathrm{dL}[1.28 \mathrm{mmol} / \mathrm{L}])$. Consistent with these findings, a restricted cubic spline analysis showed that the shape of the fully adjusted relationship between serum $\mathrm{Mg}$ levels and all-cause mortality was J shaped. Kurita et al. also employed a restricted cubic spline analysis in 2165 Japanese patients and found a similar curve for the relationship between serum $\mathrm{Mg}$ levels and all-cause mortality [70]. In Europe, de Roji van Zuijdewijn et al. demonstrated that lower serum Mg levels were associated with a high risk of all-cause and cardiovascular death as well as sudden death [71]. In these three studies [69-71], the relationship between hypomagnesemia and the mortality risk remained significant after the full adjustments. However, the findings from the USA [33, 34] were different. In Lacson's study [33], a linear decline was observed in the risk of all-cause death adjusted for case-mix variables (see Table 2) from the lowest to the highest serum $\mathrm{Mg}$ category, with the best survival in the category with the highest serum Mg levels $(>3.04 \mathrm{mg} / \mathrm{dL}$ $[1.25 \mathrm{mmol} / \mathrm{L}])$. However, the relationship between hypomagnesemia and mortality was not significant after additional adjustments for laboratory variables. Similarly, Li et al. reported that time-varying serum $\mathrm{Mg}$ levels did not predict the death in incident HD patients after adjustment for laboratory variables [34].

Thus, a relationship exists between hypomagnesemia and mortality, even after full adjustment for laboratory variables in patients from Asia and Europe [35, 69-71], but not in those from the USA [33, 34, 72]. Based on these results, it seems that patient's race or region may be involved in susceptibility to the harmful effects of hypomagnesemia. There may be another opinion that in the studies from the USA with the short dialysis duration (Table 2), the prognostic impact of hypomagnesemia might be confounded or diluted by residual renal function. Residual renal function is considered to be beneficial for the prognosis and has a negative impact on $\mathrm{Mg}$ balance even in HD patients. The median of HD duration in Lacson's study [33] was comparable to that in de Roji van Zuijdewijn's study [71]. Both Cai's [35] and Yang's study [72] included incident PD patients. However, hypomagnesemia was an independent predictor of mortality only in Cai's (from China) and de Roji van Zuijdewijn's study (from Europe).

\section{Mg-related interventions in CKD/ESRD patients}

There are two methods to increase serum Mg levels: increasing dialysate $\mathrm{Mg}$ concentrations and $\mathrm{Mg}$ supplementation. However, evidence from interventional studies to prove the favorable effects of $\mathrm{Mg}$ on cardiovascular disease and mortality is limited, which is not in proportion to the increasing interest in $\mathrm{Mg}$. These interventions should be employed with careful monitoring of serum $\mathrm{Mg}$ levels to avoid hypermagnesemia. 
Table 2 Observational studies examining the relationship between serum Mg levels and mortality

\begin{tabular}{|c|c|c|c|c|c|c|}
\hline Authors (year) & Subjects & $\begin{array}{l}\text { Dialysis } \\
\text { duration }\end{array}$ & $\begin{array}{l}\text { Dialysate } \\
\mathrm{Mg} \\
(\mathrm{mmol} / \mathrm{L})\end{array}$ & $\begin{array}{l}\text { Follow-up } \\
\text { period }\end{array}$ & Adjusted HR & Adjustments \\
\hline \multicolumn{7}{|l|}{ Pre-dialysis CKD } \\
\hline $\begin{array}{l}\text { Van } \\
\text { Laecke } \\
\text { et al. } \\
(2013) \\
{[12]}\end{array}$ & 1650 & - & - & $\begin{array}{l}\text { Median } \\
5.1 \text { years }\end{array}$ & $\begin{array}{l}\text { All-cause mortality } 0.930 \text { per } 0.1-\mathrm{mg} / \mathrm{dL} \\
\text { increase in serum Mg levels } \\
\text { All-cause mortality } 1.613 \text { in the low Mg } \\
\text { group (<1.8 mg/dL) vs. the high } \mathrm{Mg} \\
\text { group (> } 2.2 \mathrm{mg} / \mathrm{dL})\end{array}$ & $\begin{array}{l}\text { Age, sex, DM, hypertension, obesity, } \\
\text { smoking, eGFR, diuretics, RAAS blockade, } \\
\text { UA, Na, K, P, CRP }\end{array}$ \\
\hline \multicolumn{7}{|l|}{ Dialysis } \\
\hline $\begin{array}{l}\text { Sakaguchi } \\
\text { et al. } \\
(2014) \\
{[69]}\end{array}$ & $\begin{array}{l}142,555, \\
H D\end{array}$ & $\begin{array}{l}\text { Median } \\
7 \text { years }\end{array}$ & 0.5 & 1 year & $\begin{array}{l}\text { All-cause mortality } 1.28 \text {, cardiovascular } \\
\text { mortality } 1.24 \text {, non-cardiovascular } \\
\text { mortality } 1.32 \text { in the lowest Mg sextile } \\
(<2.3 \mathrm{mg} / \mathrm{dL}) \text { vs. the second highest } \\
\text { sextile }(\geq 2.8,<3.1 \mathrm{mg} / \mathrm{dL})\end{array}$ & $\begin{array}{l}\text { Age, sex, HD duration, weekly HD time, } \\
\text { BMI, DM, CVD, parathyroidectomy, hip } \\
\text { fracture, BUN, albumin, ALP, hemoglobin, } \\
\text { Ca, P, CRP, iPTH, VDRAs, PBs, cinacalcet }\end{array}$ \\
\hline $\begin{array}{l}\text { Kurita } \\
\text { et al. } \\
(2015) \\
{[70]}\end{array}$ & $\begin{array}{l}2165 \\
H D\end{array}$ & $\begin{array}{l}\text { Median } \\
8.3 \text { years }\end{array}$ & 0.5 & 3 years & $\begin{array}{l}\text { All-cause mortality } 1.734 \text { in the lowest } \\
\text { Mg quintile }(\leq 2.3 \mathrm{mg} / \mathrm{dL}) \mathrm{vs} \text {. the } \\
\text { middle quintile }(>2.5, \leq 2.7 \mathrm{mg} / \mathrm{dL}) \\
\text { All-cause mortality } 1.649 \text { in the second } \\
\text { lowest quintile }(>2.3, \leq 2.5 \mathrm{mg} / \mathrm{dL}) \mathrm{vs} \text {. } \\
\text { the middle quintile }\end{array}$ & $\begin{array}{l}\text { Age, sex, } \mathrm{HD} \text { duration, } \mathrm{Kt} / \mathrm{N} \text {, primary renal } \\
\text { disease, BMl, CVD, lung disease, liver } \\
\text { disease, malignancy, parathyroidectomy, } \\
\text { albumin, hemoglobin, } \mathrm{K}, \mathrm{Ca}, \mathrm{P}, \mathrm{CRP}, \mathrm{PPTH} \text {, } \\
\text { serum iron, ferritin }\end{array}$ \\
\hline $\begin{array}{l}\text { de Roji } \\
\text { van Zuijdewijn } \\
\text { et al. } \\
\text { (2015) [71] }\end{array}$ & $\begin{array}{l}\text { HD 184, } \\
\text { HDF } 181\end{array}$ & $\begin{array}{l}\text { Median } \\
1.8 \text { years }\end{array}$ & 0.5 & $\begin{array}{l}\text { Mean } \\
3.1 \text { years }\end{array}$ & $\begin{array}{l}\text { All-cause mortality } 0.88 \text {, cardiovascular } \\
\text { mortality } 0.73 \text {, sudden death } 0.78 \text { per } \\
0.1-\mathrm{mmol} / \mathrm{L}(0.24 \mathrm{mg} / \mathrm{dL}) \text { increase in } \\
\text { serum } \mathrm{Mg} \text { levels }\end{array}$ & $\begin{array}{l}\text { Age, sex, HD duration, weekly HD time, } \\
\text { dialysis modality (HD/HDF), residual renal } \\
\text { function, BMI, BP, DM, CVD, albumin, Ca, P, } \\
\text { iPTH }\end{array}$ \\
\hline $\begin{array}{l}\text { Lacson et al. } \\
\text { (2015) [33] }\end{array}$ & $\begin{array}{l}27,544 \\
\mathrm{HD}\end{array}$ & $\begin{array}{l}\text { Median } \\
2.5 \text { years }\end{array}$ & Various & 1 year & $\begin{array}{l}\text { All-cause mortality } 0.89 \text { in the highest } \\
\text { Mg group }(\geq 1.25 \mathrm{mmol} / \mathrm{L}) \mathrm{vs} \text {. the } \\
\text { reference group }(\geq 0.80,<0.95 \mathrm{mmol} / \\
\text { L) (not significant) }\end{array}$ & $\begin{array}{l}\text { Case mix: age, sex, race/ethnicity, } \mathrm{HD} \\
\text { duration, vascular access type, BSA } \\
\text { Laboratory: Kt } / \text {, DM, albumin, hemoglobin, } \\
\text { Ca, P, iPTH }\end{array}$ \\
\hline $\begin{array}{l}\text { Li et al. (2015) } \\
\text { [34] }\end{array}$ & $\begin{array}{l}9359 \\
H D\end{array}$ & $\begin{array}{l}\text { Incident } \\
\text { patients }\end{array}$ & $\begin{array}{l}\text { Not } \\
\text { mentioned }\end{array}$ & $\begin{array}{l}\text { Mean } \\
19 \text { months }\end{array}$ & $\begin{array}{l}\text { No relationship between time-varying } \\
\text { serum } \mathrm{Mg} \text { levels and all-cause } \\
\text { mortality after all adjustments }\end{array}$ & $\begin{array}{l}\text { Age, sex, race/ethnicity, Kt } N \text {, BMI, DM, } \\
\text { hypertension, dyslipidemia, CVD, lung } \\
\text { disease, liver disease, cancer, BUN, albumin, } \\
\text { ALP, hemoglobin, K, Ca, P, iPTH, ferritin, } \\
\text { nPCR }\end{array}$ \\
\hline $\begin{array}{l}\text { Cai et al. } \\
\text { (2016) [35] }\end{array}$ & $253, \mathrm{PD}$ & $\begin{array}{l}\text { Incident } \\
\text { patients }\end{array}$ & 0.25 & $\begin{array}{l}\text { Median } \\
29 \text { months }\end{array}$ & $\begin{array}{l}\text { All-cause mortality } 0.075 \text { in the } \\
\text { normomagnesemia group ( } \geq 1.7 \mathrm{mg} / \\
\mathrm{dL}) \text { vs. the hypomagnesemia group } \\
(<1.7 \mathrm{mg} / \mathrm{dL}) \\
\text { Cardiovascular mortality } 0.003 \text { in the } \\
\text { normomagnesemia group vs. the } \\
\text { hypomagnesemia group }\end{array}$ & $\begin{array}{l}\text { Age, sex, BMI, DM, BP, urine output, net UF, } \\
\text { weekly Ccr, residual renal function, } \\
\text { albumin, total cholesterol, triglycerides, } \\
\text { hemoglobin, } \mathrm{Na}, \mathrm{Ca}, \mathrm{P}, \mathrm{PPTH} \text {, calcium } \\
\text { carbonate, VDRAs }\end{array}$ \\
\hline $\begin{array}{l}\text { Yang et al. } \\
\text { (2016) [72] }\end{array}$ & $\begin{array}{l}10,692 \\
P D\end{array}$ & $\begin{array}{l}\text { Incident } \\
\text { patients }\end{array}$ & $\begin{array}{l}\text { Not } \\
\text { mentioned }\end{array}$ & $\begin{array}{l}\text { Median } \\
13 \text { months }\end{array}$ & $\begin{array}{l}\text { Hospitalization risk } 1.09 \text { in the lowest } \\
\text { Mg quintile }(<1.8 \mathrm{mg} / \mathrm{dL}) \mathrm{vs} \text {. the } \\
\text { middle quintile }(\geq 2.0,<2.2 \mathrm{mg} / \mathrm{dL}) \\
\text { All-cause mortality } 0.97 \text { in the lowest } \\
\text { Mg quintile vs. the middle quintile } \\
\text { (not significant) }\end{array}$ & $\begin{array}{l}\text { Age, sex, race/ethnicity, primary insurance, } \\
\text { primary renal disease, total weekly } \mathrm{Kt} / \mathrm{N}, \\
\text { residual renal function, } 4-\mathrm{h} \mathrm{D} / \mathrm{P} \mathrm{Cr} \text { ratio, } \\
\mathrm{DM} \text {, hypertension, } \mathrm{CVD} \text {, albumin, } \\
\text { hemoglobin, } \mathrm{K}, \mathrm{Ca}, \mathrm{P}, \text { bicarbonate, iPTH, } \\
\text { ferritin, iron saturation }\end{array}$ \\
\hline
\end{tabular}

Abbreviations: 4- $h$ D/P Cr ratio 4-h dialysate to plasma creatinine ratio from the peritoneal equilibration test, $A L P$ alkaline phosphatase, $B M I$ body mass index, $B P$ blood pressure, $B U N$ blood urea nitrogen, $B S A$ body surface area, $C \mathrm{Cr}$ creatinine clearance, $C K D$ chronic kidney disease, $C R P$-reactive protein, $C V D$ cardiovascular disease, DM diabetes mellitus, eGFR estimated glomerular filtration rate, HD hemodialysis, HDF hemodiafiltration, $H R$ hazard ratio, $i P T H$ intact parathyroid hormone, $n P C R$ normalized protein catabolic rate, $P B s$ phosphate binders, $P D$ peritoneal dialysis, RAAS renin-angiotensin-aldosterone system, UA uric acid, UF ultrafiltration, VDRAs vitamin $\mathrm{D}$ receptor agonists

\section{Dialysates with higher Mg concentrations}

Dialysates with higher $\mathrm{Mg}$ concentrations are feasible and effective for increasing serum Mg levels. In Nilsson's study including $22 \mathrm{HD}$ patients who had been treated with $0.75 \mathrm{mmol} / \mathrm{L}-\mathrm{Mg}$ dialysate, 12 were assigned to $0.2 \mathrm{mmol} / \mathrm{L}$ dialysate and 10 continued to use $0.75 \mathrm{mmol} / \mathrm{L}$ dialysate [58]. Four months later, the former patients showed a significant decrease in serum
Mg levels from $2.71 \pm 0.55 \mathrm{mg} / \mathrm{dL}(1.11 \pm 0.23 \mathrm{mmol} / \mathrm{L})$ to $2.26 \pm 0.54 \mathrm{mg} / \mathrm{dL} \quad(0.93 \pm 0.22 \mathrm{mmol} / \mathrm{L}, P<0.01)$, whereas the latter did not. Similar findings have been also reported in PD by Ejaz et al. [38]. None of the 33 patients had hypomagnesemia (defined as $<1.52 \mathrm{mg} / \mathrm{dL}$ $[0.625 \mathrm{mmol} / \mathrm{L}])$ with the use of $0.75 \mathrm{mmol} / \mathrm{L}-\mathrm{Mg}$ dialysate. After the change to $0.25 \mathrm{mmol} / \mathrm{L} \mathrm{Mg}$-dialysate, 21 patients (63.6\%) developed hypomagnesemia. This 
change also resulted in lower serum albumin levels in those with than in those without hypomagnesemia (2.5 $\pm 0.12 \mathrm{~g} / \mathrm{dL}$ vs. $3.2 \pm 0.12 \mathrm{~g} / \mathrm{dL}, P<0.01)$. Regardless of these findings, the effects of dialysates with higher $\mathrm{Mg}$ concentrations on cardiovascular disease and mortality have not yet been examined. Dialysate Mg-related clinical trials are of interest and need to be conducted in the future.

\section{Mg-containing phosphate binders}

It is important to control hyperphosphatemia, which leads to cardiovascular calcification and increased morbidity and mortality in CKD patients [74]. $\mathrm{Mg}$ is contained in some phosphate binders and its affinity for P is weaker than that of Al and Ca. Since the mid-1980s, magnesium hydroxide was used to replace $\mathrm{Al}$-containing phosphate binders but caused diarrhea and mild hyperkalemia [75]. Magnesium carbonate effectively controlled serum P levels with less adverse effects [75]. However, Mg-containing phosphate binders have not been widely used because of concerns regarding hypermagnesemia. In 2010, a randomized controlled trial (RCT), the CALMAG study, which compared the efficacy of calcium acetate/magnesium carbonate and sevelamer hydrochloride in HD patients, was reported [59]. At week 25, mean reductions in serum P from baseline in the calcium acetate/magnesium carbonate group and sevelamer group were similar. Serum $\mathrm{Mg}$ levels in the former group significantly increased from baseline $(0.73$ $\pm 0.56 \mathrm{mg} / \mathrm{dL}[0.30 \pm 0.23 \mathrm{mmol} / \mathrm{L}])$, whereas a slight increase was observed in the latter group $(0.10 \pm 0.36 \mathrm{mg} /$ $\mathrm{dL} \quad[0.04 \pm 0.15 \mathrm{mmol} / \mathrm{L}])$. Gastrointestinal adverse events occurred more frequently in the sevelamer group (23.6 vs. $13.6 \%$ ). The authors concluded that magnesium carbonate was a tolerable and effective agent in the treatment of hyperphosphatemia.

A few interventional studies have examined the effects of Mg-containing phosphate binders on cardiovascular lesions, as shown in Table 3 [76, 77]. Furthermore, their effects on mortality currently remain unknown. Tzanakis et al. randomly assigned $59 \mathrm{HD}$ patients to calcium acetate or calcium acetate/magnesium carbonate for 12 months [77]. At the end of the study, the number of patients with improved carotid IMT was significantly higher in the Mg-containing phosphate binder group than in the Ca-containing binder group $(P=0.04)$. Turgut et al. also showed the beneficial effects of $\mathrm{Mg}$ supplementation [76]. However, these findings appeared to be inconclusive because of the relatively small sample size as well as the accuracy and reproducibility of the evaluation methods.

In a sub-analysis of the aforementioned Japanese National Registry data [69], Sakaguchi et al. reported that the mortality risk of HD patients with hyperphosphatemia was attenuated with increases in serum $\mathrm{Mg}$ levels [78]. If large-scale RCTs successfully show the benefits of Mg-containing phosphate binders for cardiovascular disease and mortality, these drugs may be widely used in the control of hyperphosphatemia.

\section{Mg-containing laxatives}

The prevalence of constipation requiring laxative therapy is high in ESRD patients $[79,80]$. Mg-containing laxatives may be used to concurrently treat constipation and hypomagnesemia. However, these drugs should be used carefully. Serum Mg levels were increased to approximately $10 \mathrm{mg} / \mathrm{dL}(4.11 \mathrm{mmol} / \mathrm{L})$ by magnesium oxide administered at $3 \mathrm{~g} /$ day in dialysis patients, resulting in muscle paresis or impaired consciousness [81, 82]. Toprak et al. conducted a RCT including 128 prediabetic patients with hypomagnesemia $(<1.8 \mathrm{mg} / \mathrm{dL}$ $[0.74 \mathrm{mmol} / \mathrm{L}]$ in males and $<1.9 \mathrm{mg} / \mathrm{dL}[0.78 \mathrm{mmol} / \mathrm{L}]$ in females) and mild to moderate CKD (estimated GFR $30-60 \mathrm{~mL} / \mathrm{min} / 1.73 \mathrm{~m}^{2}$ ) [83]. Patients were assigned to magnesium oxide or placebo for 3 months. Magnesium oxide was administered at $613.2 \mathrm{mg} /$ day and serum $\mathrm{Mg}$ levels increased from $1.70 \pm 0.13 \mathrm{mg} / \mathrm{dL} \quad(0.70 \pm$ $0.05 \mathrm{mmol} / \mathrm{L})$ to $1.91 \pm 0.22 \mathrm{mg} / \mathrm{dL}(0.79 \pm 0.09 \mathrm{mmol} /$ L). At the end of this study, insulin resistance, glycemic control, and uric acid levels were better in the former than in the latter patient group. These improvements in metabolic indices were accompanied by an increase in not only serum $\mathrm{Mg}$, but also albumin levels.

Table 3 Interventional studies examining effects of Mg-containing phosphate binders on cardiovascular calcification/atherosclerosis

\begin{tabular}{|c|c|c|c|c|c|}
\hline $\begin{array}{l}\text { Authors } \\
\text { (year) }\end{array}$ & Subjects & Study design & Outcome & $\begin{array}{l}\text { Serum } M g \\
\text { levels in the Mg } \\
\text { group }(\mathrm{mg} / \mathrm{dL})\end{array}$ & $\begin{array}{l}\text { Benefits of } \mathrm{Mg} \\
\text { supplementation }\end{array}$ \\
\hline $\begin{array}{l}\text { Turgut } \\
\text { et al. } \\
\text { (2008) } \\
{[76]}\end{array}$ & $47, \mathrm{HD}$ & $\begin{array}{l}\text { RCT with assignment to magnesium } \\
\text { citrate or calcium acetate for } 2 \text { months }\end{array}$ & $\begin{array}{l}\text { Changes in carotid intima-media } \\
\text { thickness evaluated by ultrasound }\end{array}$ & $\begin{array}{l}\text { Pre: } 2.50 \pm 0.36 \\
\text { Post: } 2.69 \pm 0.39\end{array}$ & Yes \\
\hline $\begin{array}{l}\text { Tzanakis } \\
\text { et al. } \\
(2014) \\
{[77]}\end{array}$ & $72, \mathrm{HD}$ & $\begin{array}{l}\text { RCT with assignment to calcium } \\
\text { acetate or calcium acetate/magnesium } \\
\text { carbonate for } 12 \text { months }\end{array}$ & $\begin{array}{l}\text { Changes in arterial calcification of the femur, } \\
\text { pelvis, hands, and abdomen evaluated by plain } \\
\text { X-ray using vascular calcification scores }\end{array}$ & $\begin{array}{l}\text { Pre: } 2.59 \pm 0.29 \\
\text { Post: } 2.83 \pm 0.38\end{array}$ & Yes \\
\hline
\end{tabular}




\section{Sevelamer}

Sevelamer is a Ca-free, $\mathrm{Mg}$-free, non-absorbable anion exchange resin that is used to control hyperphosphatemia. There are two salts of sevelamer: sevelamer hydrochloride and sevelamer carbonate. This drug has been reported to increase serum $\mathrm{Mg}$ levels. Mitsopoulos et al. found that the mean serum $\mathrm{Mg}$ levels significantly increased from $2.75 \mathrm{mg} / \mathrm{dL}(1.13 \mathrm{mmol} / \mathrm{L})$ to $2.90 \mathrm{mg} / \mathrm{dL}(1.19 \mathrm{mmol} / \mathrm{L})$ during an 8-week treatment with sevelamer [84]. Chertow et al. also reported a significant increase in serum $\mathrm{Mg}$ levels induced by sevelamer [85]. In addition, two cross-sectional studies showed an independent relationship between sevelamer and higher serum $\mathrm{Mg}$ levels $[36,86]$. It seems plausible to speculate that this effect of sevelamer depends on its adsorptive action on some substances other than P. Free fatty acids in the intestinal lumen may combine with $\mathrm{Mg}$ to form non-absorbable soaps. Therefore, Mitsopoulos et al. speculated that sevelamer binds biliary salts, thereby increasing the quantity of free $\mathrm{Mg}$ available for intestinal absorption [84]. On the other hand, Nagano et al. reported the contribution of magnesium stearate, which is included as a pharmaceutical excipient in phosphate binders, to increases in serum $\mathrm{Mg}$ levels [87].

Sevelamer has been reported to exert favorable effects on inflammation, oxidative stress, glucose metabolism, lipid profiles, and cardiovascular disease [88, 89], similar to $\mathrm{Mg}$ supplementation. Although the precise mechanisms responsible for these effects of sevelamer have not yet been elucidated, the increases in serum $\mathrm{Mg}$ levels induced by the drug itself may be included in these mechanisms.

\section{Conclusions}

In the clinical practice of dialysis therapy, concerns need to shift from hypermagnesemia to hypomagnesemia. Dialysis patients, particularly those treated with PD, are exposed to the risk of hypomagnesemia because of the use of dialysates with low $\mathrm{Mg}$ concentrations as well as decreased intake/absorption and the adverse effects of some drugs. Observational studies have almost consistently indicated that hypomagnesemia is associated with cardiovascular disease and mortality in CKD. However, this relationship may depend on a patient's race or region. Dialysates with higher $\mathrm{Mg}$ concentrations and some drugs including phosphate binders are useful for increasing serum Mg levels, but few interventional studies have examined the benefits of the correction of hypomagnesemia. Further studies are required in order to establish the efficacy of Mg supplementation in CKD patients. In addition, it is important to establish the harmless upper limit of serum Mg levels.

\section{Abbreviations}

BMP: Bone morphogenetic protein; CKD: Chronic kidney disease;

CPP: Calciprotein particle; DM: Diabetes mellitus; ESRD: End-stage renal disease; GFR: Glomerular filtration rate; HD: Hemodialysis; HR: Hazard ratio; IMT: Intima-media thickness; PD: Peritoneal dialysis; PTH: Parathyroid hormone; RCT: Randomized controlled trial; VSMC: Vascular smooth muscle cell

\section{Acknowledgements}

Not applicable

Funding

Not applicable

Availability of data and materials

Not applicable

Ethics approval and consent to participate

Not applicable

Consent for publication

Not applicable

Competing interests

The author declares no competing interest.

\section{Publisher's Note}

Springer Nature remains neutral with regard to jurisdictional claims in published maps and institutional affiliations.

Received: 25 August 2017 Accepted: 14 December 2017

Published online: 10 January 2018

\section{References}

1. Altura BM, Altura BT. New perspectives on the role of magnesium in the pathophysiology of the cardiovascular system. I Clinical aspects Magnesium. 1985:4:226-44.

2. Shechter M, Merz CN, Paul-Labrador M, Meisel SR, Rude RK, Molloy MD, et al. Oral magnesium supplementation inhibits platelet-dependent thrombosis in patients with coronary artery disease. Am J Cardiol. 1999;84: 152-6.

3. Shechter M, Sharir M, Labrador MJ, Forrester J, Silver B, Bairey Merz CN. Oral magnesium therapy improves endothelial function in patients with coronary artery disease. Circulation. 2000;102:2353-8.

4. Chen X, Mak IT. Mg supplementation protects against ritonavir-mediated endothelial oxidative stress and hepatic eNOS downregulation. Free Radic Biol Med. 2014;69:77-85.

5. Grober U, Schmidt J, Kisters K. Magnesium in prevention and therapy. Nutrients. 2015;7:8199-226

6. Guerrero-Romero F, Rodriguez-Moran M. Low serum magnesium levels and metabolic syndrome. Acta Diabetol. 2002;39:209-13.

7. Song Y, Ridker PM, Manson JE, Cook NR, Buring JE, Liu S. Magnesium intake, C-reactive protein, and the prevalence of metabolic syndrome in middle-aged and older U.S. women. Diabetes Care. 2005;28:1438-44.

8. Evangelopoulos AA, Vallianou NG, Panagiotakos DB, Georgiou A, Zacharias $\mathrm{GA}$, Alevra AN, et al. An inverse relationship between cumulating components of the metabolic syndrome and serum magnesium levels. Nutr Res. 2008;28:659-63.

9. Sarnak MJ, Levey AS, Schoolwerth AC, Coresh J, Culleton B, Hamm LL, et al. Kidney disease as a risk factor for development of cardiovascular disease: a statement from the American Heart Association Councils on Kidney in Cardiovascular Disease, High Blood Pressure Research, Clinical Cardiology, and Epidemiology and Prevention. Circulation. 2003;108:2154-69.

10. Kanbay M, Goldsmith D, Uyar ME, Turgut F, Covic A. Magnesium in chronic kidney disease: challenges and opportunities. Blood Purif. 2010;29:280-92.

11. Sakaguchi Y, Shoji T, Hayashi T, Suzuki A, Shimizu M, Mitsumoto K, et al. Hypomagnesemia in type 2 diabetic nephropathy: a novel predictor of endstage renal disease. Diabetes Care. 2012;35:1591-7.

12. Van Laecke S, Nagler EV, Verbeke F, Van Biesen W, Vanholder R. Hypomagnesemia and the risk of death and GFR decline in chronic kidney disease. Am J Med. 2013;126:825-31. 
13. Tin A, Grams ME, Maruthur NM, Astor BC, Couper D, Mosley TH, et al. Results from the Atherosclerosis Risk in Communities study suggest that low serum magnesium is associated with incident kidney disease. Kidney Int. 2015:87:820-7.

14. Sakaguchi $Y$, Iwatani H, Hamano T, Tomida K, Kawabata H, Kusunoki Y, et al. Magnesium modifies the association between serum phosphate and the risk of progression to end-stage kidney disease in patients with nondiabetic chronic kidney disease. Kidney Int. 2015;88:833-42.

15. Dousdampanis P, Trigka K, Fourtounas C. Hypomagnesemia, chronic kidney disease and cardiovascular mortality: pronounced association but unproven causation. Hemodial Int. 2014;18:730-9.

16. Rebholz CM, Tin A, Liu Y, Kuczmarski MF, Evans MK, Zonderman AB, et al. Dietary magnesium and kidney function decline: the healthy aging in neighborhoods of diversity across the life span study. Am J Nephrol. 2016; 44:381-7.

17. Futrakul $P$, Yenrudi $S$, Futrakul N, Sensirivatana R, Kingwatanakul $P$, Jungthirapanich J, et al. Tubular function and tubulointerstitial disease. Am J Kidney Dis. 1999;33:886-91.

18. Noiri C, Shimizu T, Takayanagi K, Tayama Y, Iwashita T, Okazaki S, et al. Clinical significance of fractional magnesium excretion (FEMg) as a predictor of interstitial nephropathy and its correlation with conventional parameters. Clin Exp Nephrol. 2015;19:1071-8.

19. Mordes JP, Wacker WE. Excess magnesium. Pharmacol Rev. 1977;29:273-300.

20. Coburn JW, Popovtzer MM, Massry SG, Kleeman CR. The physicochemical state and renal handling of divalent ions in chronic renal failure. Arch Intern Med. 1969;124:302-11.

21. Massry SG. Magnesium homeostasis in patients with renal failure. Contrib Nephrol. 1984;38:175-84

22. Dewitte K, Dhondt A, Giri M, Stockl D, Rottiers R, Lameire N, et al. Differences in serum ionized and total magnesium values during chronic renal failure between nondiabetic and diabetic patients: a cross-sectional study. Diabetes Care. 2004:27:2503-5.

23. Djurhuus MS, Skott P, Hother-Nielson O, Klitgaard NA, Beck-Nielsen $H$. Insulin increases renal magnesium excretion: a possible cause of magnesium depletion in hyperinsulinaemic states. Diabet Med. 1995;12: 664-9.

24. Ye H, Zhang X, Guo Q, Huang N, Mao H, Yu X, et al. Prevalence and factors associated with hypomagnesemia in Southern Chinese continuous ambulatory peritoneal dialysis patients. Perit Dial Int. 2013;33:450-4.

25. Gonella M, Ballanti P, Della Rocca C, Calabrese G, Pratesi G, Vagelli G, et al. Improved bone morphology by normalizing serum magnesium in chronically hemodialyzed patients. Miner Electrolyte Metab. 1988:14:240-5.

26. Graf H, Kovarik J, Stummvoll HK, Wolf A. Disappearance of uraemic pruritus after lowering dialysate magnesium concentration. Br Med J. 1979;2:1478-9.

27. Contiguglia SR, Alfrey AC, Miller NL, Runnells DE, Le Geros RZ. Nature of soft tissue calcification in uremia. Kidney Int. 1973;4:229-35.

28. Wyskida K, Witkowicz J, Chudek J, Więcek A. Daily magnesium intake and hypermagnesemia in hemodialysis patients with chronic kidney disease. J Ren Nutr. 2012:22:19-26.

29. Brannan PG, Vergne-Marini P, Pak CY, Hull AR, Fordtran JS. Magnesium absorption in the human small intestine. Results in normal subjects, patients with chronic renal disease, and patients with absorptive hypercalciuria. J Clin Invest. 1976:57:1412-8.

30. Schmulen AC, Lerman M, Pak CY, Zerwekh J, Morawski S, Fordtran JS, et al. Effect of 1,25-(OH) ${ }_{2} \mathrm{D}_{3}$ on jejunal absorption of magnesium in patients with chronic renal disease. Am J Phys. 1980;238:G349-52.

31. Luis D, Zlatkis K, Comenge B, Garcia Z, Navarro JF, Lorenzo V, et al. Dietary quality and adherence to dietary recommendations in patients undergoing hemodialysis. J Ren Nutr. 2016;26:190-5.

32. Liu F, Zhang X, Qi H, Wang J, Wang M, Zhang Y, et al. Correlation of serum magnesium with cardiovascular risk factors in maintenance hemodialysis patients-a cross-sectional study. Magnes Res. 2013:26:100-8.

33. Lacson E Jr, Wang W, Ma L, Passlick-Deetjen J. Serum magnesium and mortality in hemodialysis patients in the United States: a cohort study. Am J Kidney Dis. 2015;66:1056-66.

34. Li L, Streja E, Rhee CM, Mehrotra R, Soohoo M, Brunelli SM, et al. Hypomagnesemia and mortality in incident hemodialysis patients. Am J Kidney Dis. 2015;66:1047-55.

35. Cai K, Luo Q, Dai Z, Zhu B, Fei J, Xue C, et al. Hypomagnesemia is associated with increased mortality among peritoneal dialysis patients. PLoS One. 2016;1:e0152488.
36. Ikee R, Toyoyama T, Endo T, Tsunoda M, Hashimoto N. Impact of sevelamer hydrochloride on serum magnesium concentrations in hemodialysis patients. Magnes Res. 2016;29:184-90.

37. Okazaki H, Ishimura E, Okuno S, Norimine K, Yamakawa K, Yamakawa T, et al. Significant positive relationship between serum magnesium and muscle quality in maintenance hemodialysis patients. Magnes Res. 2013;26:182-7.

38. Ejaz AA, McShane AP, Gandhi VC, Leehey DJ, Ing TS. Hypomagnesemia in continuous ambulatory peritoneal dialysis patients dialyzed with a lowmagnesium peritoneal dialysis solution. Perit Dial Int. 1995;15:61-4.

39. Shroff RC, McNair R, Figg N, Skepper JN, Schurgers L, Gupta A, et al. Dialysis accelerates medial vascular calcification in part by triggering smooth muscle cell apoptosis. Circulation. 2008;118:1748-57.

40. Temmar M, Liabeuf S, Renard C, Czernichow S, Esper NE, Shahapuni I, et al. Pulse wave velocity and vascular calcification at different stages of chronic kidney disease. J Hypertens. 2010;28:163-9.

41. Ohtake T, Kobayashi S. Impact of vascular calcification on cardiovascular mortality in hemodialysis patients: clinical significance, mechanisms and possible strategies for treatment. Renal Replacement Therapy. 2017;3:13.

42. ter Braake AD, Shanahan CM, de Baaij JH. Magnesium counteracts vascular calcification: passive interference or active modulation? Arterioscler Thromb Vasc Biol. 2017:37:1431-45.

43. Apfelbaum F, Mayer I, Rey C, Lebugle A. Magnesium in maturing synthetic apatite: a Fourier transform infrared analysis. J Cryst Growth. 1994;144:304-10.

44. Heiss A, DuChesne A, Denecke B, Grotzinger J, Yamamoto K, Renne T, et al. Structural basis of calcification inhibition by a 2-HS glycoprotein/ fetuin-A. Formation of colloidal calciprotein particles. J Biol Chem. 2003; 278:13333-41.

45. Aghagolzadeh P, Bachtler M, Bijarnia R, Jackson C, Smith ER, Odermatt A, et al. Calcification of vascular smooth muscle cells is induced by secondary calciprotein particles and enhanced by tumor necrosis factor-a. Atherosclerosis. 2016;251:404-14.

46. Pasch A, Block GA, Bachtler M, Smith ER, Jahnen-Dechent W, Arampatzis S, et al. Blood calcification propensity, cardiovascular events, and survival in patients receiving hemodialysis in the EVOLVE trial. Clin J Am Soc Nephrol. 2017;12:315-22.

47. Keyzer CA, de Borst MH, van den Berg E, Jahnen-Dechent W, Arampatzis S, Farese $\mathrm{S}$, et al. Calcification propensity and survival among renal transplant recipients. J Am Soc Nephrol. 2016:27:239-48.

48. Pasch A, Farese S, Graber S, Wald J, Richtering W, Floege J, et al. Nanoparticle-based test measures overall propensity for calcification in serum. J Am Soc Nephrol. 2012;23:1744-52.

49. Montes de Oca A, Guerrero F, Martinez-Moreno JM, Madueno JA, Herencia C, Peralta A, et al. Magnesium inhibits Wnt/ $\beta$-catenin activity and reverses the osteogenic transformation of vascular smooth muscle cells. PLoS One. 2014:9:e89525.

50. Montezano AC, Zimmerman D, Yusuf H, Burger D, Chignalia AZ, Wadhera V, et al. Vascular smooth muscle cell differentiation to an osteogenic phenotype involves TRPM7 modulation by magnesium. Hypertension. 2010; 56:453-62.

51. Sonou T, Ohya M, Yashiro M, Masumoto A, Nakashima Y, Ito T, et al. Magnesium prevents phosphate-induced vascular calcification via TRPM7 and Pit-1 in an aortic tissue culture model. Hypertens Res. 2017;40:562-7.

52. Mune S, Shibata M, Hatamura I, Saji F, Okada T, Maeda Y, et al. Mechanism of phosphate-induced calcification in rat aortic tissue culture: possible involvement of Pit-1 and apoptosis. Clin Exp Nephrol. 2009;13:571-7.

53. Coen G, Manni M, Mantella D, Pierantozzi A, Balducci A, Condo S, et al. Are PTH serum levels predictive of coronary calcifications in haemodialysis patients? Nephrol Dial Transplant. 2007;22:3262-7.

54. Neves KR, Graciolli FG, dos Reis LM, Graciolli RG, Neves CL, Magalhaes AO, et al. Vascular calcification: contribution of parathyroid hormone in renal failure. Kidney Int. 2007;71:1262-70.

55. Ohya M, Negi S, Sakaguchi T, Koiwa F, Ando R, Komatsu Y, et al. Significance of serum magnesium as an independent correlative factor on the parathyroid hormone level in uremic patients. J Clin Endocrinol Metab. 2014;99:3873-8

56. Navarro JF, Mora C, Macia M, Garcia J. Serum magnesium concentration is an independent predictor of parathyroid hormone levels in peritoneal dialysis patients. Perit Dial Int. 1999;19:455-61.

57. Gohda T, Shou I, Fukui M, Funabiki K, Horikoshi S, Shirato I, et al. Parathyroid hormone gene polymorphism and secondary hyperparathyroidism in hemodialysis patients. Am J Kidney Dis. 2002;39:1255-60. 
58. Nilsson P, Johansson SG, Danielson BG. Magnesium studies in hemodialysis patients before and after treatment with low dialysate magnesium. Nephron. 1984;37:25-9.

59. de Francisco AL, Leidig M, Covic AC, Ketteler M, Benedyk-Lorens E, Mircescu $\mathrm{GM}$, et al. Evaluation of calcium acetate/magnesium carbonate as a phosphate binder compared with sevelamer hydrochloride in haemodialysis patients: a controlled randomized study (CALMAG study) assessing efficacy and tolerability. Nephrol Dial Transplant. 2010;25:3707-17.

60. Kyriazis J, Kalogeropoulou K, Bilirakis L, Smirnioudis N, Pikounis V, Stamatiadis D, et al. Dialysate magnesium level and blood pressure. Kidney Int. 2004;66:1221-31.

61. Alabd MA, El-Hammady W, Shawky A, Nammas W, El-Tayeb M. QT interval and QT dispersion in patients undergoing hemodialysis: revisiting the old theory. Nephron Extra. 2011;1:1-8.

62. Meema HE, Oreopoulos DG, Rapoport A. Serum magnesium level and arterial calcification in end-stage renal disease. Kidney Int. 1987;32:388-94.

63. Tzanakis I, Pras A, Kounali D, Mamali V, Kartsonakis V, MayopoulouSymvoulidou D, et al. Mitral annular calcifications in haemodialysis patients: a possible protective role of magnesium. Nephrol Dial Transplant. 1997;12: 2036-7.

64. Tamashiro M, Iseki $K$, Sunagawa O, Inoue T, Higa S, Afuso H, et al. Significant association between the progression of coronary artery calcification and dyslipidemia in patients on chronic hemodialysis. Am J Kidney Dis. 2001;38: 64-9.

65. Tzanakis I, Virvidakis K, Tsomi A, Mantakas E, Girousis N, Karefyllakis N, et al. Intra- and extracellular magnesium levels and atheromatosis in haemodialysis patients. Magnes Res. 2004;17:102-8.

66. Ishimura E, Okuno S, Kitatani K, Tsuchida T, Yamakawa T, Shioi A, et al. Significant association between the presence of peripheral vascular calcification and lower serum magnesium in hemodialysis patients. Clin Nephrol. 2007:68:222-7.

67. Sakaguchi Y, Hamano T, Nakano C, Obi Y, Matsui I, Kusunoki Y, et al. Association between density of coronary artery calcification and serum magnesium levels among patients with chronic kidney disease. PLoS One. 2016;11:e0163673.

68. Molnar AO, Biyani M, Hammond I, Harmon JP, Lavoie S, McCormick B, et al. Lower serum magnesium is associated with vascular calcification in peritoneal dialysis patients: a cross sectional study. BMC Nephrol. 2017;18:129.

69. Sakaguchi Y, Fujii N, Shoji T, Hayashi T, Rakugi H, Isaka Y. Hypomagnesemia is a significant predictor of cardiovascular and non-cardiovascular mortality in patients undergoing hemodialysis. Kidney Int. 2014;85:174-81.

70. Kurita N, Akizawa T, Fukagawa M, Onishi Y, Kurokawa K, Fukuhara S. Contribution of dysregulated serum magnesium to mortality in hemodialysis patients with secondary hyperparathyroidism: a 3-year cohort study. Clin Kidney J. 2015;8:744-52.

71. de Roij van Zuijdewijn CL, Grooteman MP, Bots ML, Blankestijn PJ, Steppan S, Buchel J, et al. Serum magnesium and sudden death in European hemodialysis patients. PLoS One. 2015;10:e0143104.

72. Yang X, Soohoo M, Streja E, Rivara MB, Obi Y, Adams SV, et al. Serum magnesium levels and hospitalization and mortality in incident peritoneal dialysis patients: a cohort study. Am J Kidney Dis. 2016;68:619-27.

73. Ishimura E, Okuno S, Yamakawa T, Inaba M, Nishizawa Y. Serum magnesium concentration is a significant predictor of mortality in maintenance hemodialysis patients. Magnes Res. 2007;20:237-44.

74. Covic A, Kothawala P, Bernal M, Robbins S, Chalian A, Goldsmith D. Systematic review of the evidence underlying the association between mineral metabolism disturbances and risk of all-cause mortality, cardiovascular mortality and cardiovascular events in chronic kidney disease. Nephrol Dial Transplant. 2009;24:1506-23.

75. Spiegel DM. The role of magnesium binders in chronic kidney disease Semin Dial. 2007;20:333-6.

76. Turgut F, Kanbay M, Metin MR, Uz E, Akcay A, Covic A. Magnesium supplementation helps to improve carotid intima media thickness in patients on hemodialysis. Int Urol Nephrol. 2008:40:1075-82.

77. Tzanakis IP, Stamataki EE, Papadaki AN, Giannakis N, Damianakis NE, Oreopoulos DG. Magnesium retards the progress of the arterial calcifications in hemodialysis patients: a pilot study. Int Urol Nephrol. 2014;46:2199-205.

78. Sakaguchi Y, Fujii N, Shoji T, Hayashi T, Rakugi H, Iseki K, et al. Magnesium modifies the cardiovascular mortality risk associated with hyperphosphatemia in patients undergoing hemodialysis: a cohort study. PLoS One. 2014;9:e116273.
79. Sutton D, Dumbleton S, Allaway C. Can increased dietary fibre reduce laxative requirement in peritoneal dialysis patients? J Ren Care. 2007;33: $174-8$.

80. Ikee R, Toyoyama T, Endo T, Tsunoda M, Hashimoto N. Clinical factors associated with constipation in hemodialysis patients. Int Urol Nephrol. 2016:48:1741-2

81. Matsuo H, Nakamura K, Nishida A, Kubo K, Nakagawa R, Sumida Y. A case of hypermagnesemia accompanied by hypercalcemia induced by a magnesium laxative in a hemodialysis patient. Nephron. 1995;71:477-8.

82. Jung GJ, Gil HW, Yang JO, Lee EY, Hong SY. Severe hypermagnesemia causing quadriparesis in a CAPD patient. Perit Dial Int. 2008;28:206.

83. Toprak O, Kurt H, Sari Y, Sarkis C, Us H, Kirik A. Magnesium replacement improves the metabolic profile in obese and pre-diabetic patients with mild-to-moderate chronic kidney disease: a 3-month, randomised, double-blind, placebo-controlled study. Kidney Blood Press Res. 2017;42: 33-42.

84. Mitsopoulos E, Griveas I, Zanos S, Anagnostopoulos K, Giannakou A, Pavlitou A, et al. Increase in serum magnesium level in haemodialysis patients receiving sevelamer hydrochloride. Int Urol Nephrol. 2005;37:321-8.

85. Chertow GM, Burke SK, Dillon MA, Slatopolsky E. Long-term effects of sevelamer hydrochloride on the calcium $\times$ phosphate product and lipid profile of haemodialysis patients. Nephrol Dial Transplant. 1999;14:2907-14.

86. Rosa-Diez G, Negri AL, Crucelegui MS, Philippi R, Perez-Teysseyre H, SarabiaReyes $\mathrm{C}$, et al. Sevelamer carbonate reduces the risk of hypomagnesemia in hemodialysis-requiring end-stage renal disease patients. Clin Kidney J. 2016; 9:481-5.

87. Nagano N, Ito K, Honda M, Sunaga S, Tagahara A, Nohara T, et al. The magnesium included as a pharmaceutical excipient in phosphate binders might affect the serum magnesium levels of dialysis patients. J Jpn Soc Dial Ther. 2016;49:571-80. (in Japanese)

88. Ikee R, Tsunoda M, Sasaki N, Sato N, Hashimoto N. Emerging effects of sevelamer in chronic kidney disease. Kidney Blood Press Res. 2013;37:24-32.

89. Ikee R, Hashimoto N. Glucose-lowering effect of sevelamer hydrochloride in hemodialysis patients. Ther Apher Dial. 2015;19:412-3.

\section{Submit your next manuscript to BioMed Central and we will help you at every step:}

- We accept pre-submission inquiries

- Our selector tool helps you to find the most relevant journal

- We provide round the clock customer support

- Convenient online submission

- Thorough peer review

- Inclusion in PubMed and all major indexing services

- Maximum visibility for your research

Submit your manuscript at www.biomedcentral.com/submit 